\section{DEL SOMBRERO AL ÁRBOL. RELATOS ICÓNICOS DE LA NACIÓN COLOMBIANA}

\author{
Beatriz González Aranda \\ Maestra en Bellas Artes, Historiadora, \\ Miembro del Consejo Asesor de Artes Plásticas \\ del Banco de la República (Colombia) \\ Carrera 5 \# 26 - 57 Torre A - Apartamento 3001 \\ beatrizgonzaleza@yahoo.com
}

\section{FROM HAT TO TREE. ICONIC TALES OF THE COLOMBIAN NATION}

\begin{abstract}
In four episodes the way is narrated as four objects of the movable patrimony became iconic stories of the Colombian nation: The first episode talks about to the painting of Pedro Jose Figueroa, Post Nubila Faebus. SIMÓN BOLIVAR, LIBERATOR y Padre de la patria, that makes the transit of the concepts of Freedom, Mother country, Colombia and Allegory of America. The second episode deals with the diffusion of "the Tree of the Freedom" in the Nuevo reino de Granada during the Illustration and the change that suffered due to the declaration of Independence. A work of anonymous author can be considered like the representation of the ceremony of seedtime of the tree. The rooted transit of the mother country concept is analyzed so, to its loss of prestige and at the present time, to its vindication. The third episode narrates of how the Poporo quimbaya got to become icon, between near 33,600 pieces of the Museo del Oro del Banco de la República. Their geometric form, the material and myth of El Dorado, contributed to their iconizacion. The fourth episode deals with the Virgen de Chiquinquirá (La Chinca) (1556) tie to the miracle of the renovation in the society colony. The colony with independence, the devotion with the nationality connects itself. One concludes with a question on Whom it creates the representations of the nationality, the artist, the town, the museums? and on the validity of the iconográfics representations.
\end{abstract}

KEY WORDS: Representation; mother country; iconography; essential; tree; freedom; icon; to re-examine; independence; emblematic; identity.

\section{INTRODUCCIÓN}

¿Un sombrero puede ser una representación iconográfica de la nación en Iberoamérica? En julio de 2006 fue convocado un grupo interdisciplinario -comité de sabios- por la revista Semana para indagar sobre los símbolos de la nación colombiana; esto es, sobre cómo se debía significar, representar o denotar el concepto de nación en Colombia. Los directores de Semana seguían paso a paso las expe-
RESUMEN: En cuatro episodios se narra el modo cómo cuatro objetos del patrimonio mueble se convirtieron en relatos icónicos de la nación colombiana: el primer episodio se refiere a la pintura de Pedro José Figueroa, Post Nubila Faebus. SIMÓN BOLIVAR, LIBERTADOR y Padre de la Patria que hace el tránsito de los conceptos de Libertad $\rightarrow$ Patria $\rightarrow$ Colombia $\rightarrow$ Alegoría de América. El segundo episodio trata de la difusión de "el Árbol de la Libertad" en el Nuevo Reino de Granada durante la llustración y el cambio que sufrió debido a la declaración de Independencia. Una obra de autor anónimo puede considerarse como la representación de la ceremonia de la siembra del árbol. Se analiza el tránsito tan arraigado del concepto de patria, a su desprestigio y en la actualidad, a su reivindicación. El tercer episodio narra de cómo llegó a convertirse en icono el Poporo quimbaya, entre las cerca de 33.600 piezas del Museo del Oro del Banco de la República. Su forma geométrica, el material y mito de El Dorado, contribuyeron a su iconización. El cuarto episodio trata de la Virgen de Chiquinquirá (La Chinca) (1556) vinculada al milagro de la renovación en la sociedad colonia. Se conecta la colonia con la independencia, la devoción con la nacionalidad. Se concluye con una pregunta sobre ¿Quién crea las representaciones de la nacionalidad, el artista, el pueblo, los museos? y sobre la validez de las representaciones iconográficas.

PALABRAS CLAVES: Representación; patria; iconografia; esencial; árbol; libertad; icono; reexaminar; independencia; emblemática; identidad.

riencias del Reino Unido, Italia y España que ese mismo año "eligieron, a través del voto on line, el símbolo nacional que mejor representara su cultura". Al finalizar el trabajo de grupo en Semana elaboró una lista de cincuenta símbolos seleccionados por el comité y el público y al final el lector votó. La experiencia fue frustrante para la mayoría de los miembros del comité a causa de la intervención mediática que puso en riesgo la calidad y por poco permitió que la ligereza dominara la sabiduría. ¡Preseleccionar las reinas 
de belleza como representativos del concepto nación era un acto de irresposabilidad! Los diez primeros símbolos escogidos por el voto on line fueron: El sombrero vueltiao, el café, el carnaval de Barranquilla, la orquídea (Catleya Triana), la bandera, la estatuaria de San Agustín (sitio arqueológico), la chiva (vehículo folclórico interpretado en cerámica), la leyenda de El Dorado, El Divino Niño y las esmeraldas.

El problema de estas selecciones es que algunas representaciones no son originarias del lugar o del país. Por ejemplo el café, provino de Arabia, el "Divino Niño" es una devoción colombiana hacia una imagen europea y las esmeraldas se encuentran en distintos territorios del planeta. Sin embargo, es difícil establecer el instante en que La Monalisa se convirtió en representación de Francia. ¿Qué circunstancias, condiciones y caracteristicas permitieron que entre todas las obras producidas por el genio francés se elija al genio italiano de Leonardo? La Monalisa, una obra pintada por un italiano, que representa a una mujer también italiana, entró a formar parte del imaginario popular francés.

Según el Diccionario de símbolos las representaciones pueden ser abstractas o concretas como animales, artefactos, el cielo y la tierra, el cuerpo humano, el vestido y las plantas. En el concurso de la revista Semana se eligió un artefacto: "el sombrero vueltiao", una pieza artesanal de fibra de caña flecha trenzada, de color blanco y negro (fig. 1). Su procedencia ha sido adjudicada por los estudiosos a la cultura Zenú del norte de Colombia. En la carátula de la edición especial de la revista se publicó la fotografía de un niño rubio de ojos azules ataviado con el sombrero. Parecía pensado para ironizar la representación y la contra-representación del país. En el subtítulo decía "Los colombianos eligieron el sombrero vueltiao como el símbolo que más los representa."

\section{Después de las tinieblas sale el sol}

A partir del siglo XIX, en el que tuvo lugar la Independencia, en estos paises que habian pasado por siglos de colonización, existió una inquietud sobre la identidad. No obstante, los rezagos traumáticos de la conquista y la colonia impidieron responder a la pregunta "quiénes somos"; y sólo a través de sistemas foráneos y de las enseñanzas de la llustración fue posible aproximarse al "cómo somos". Fue

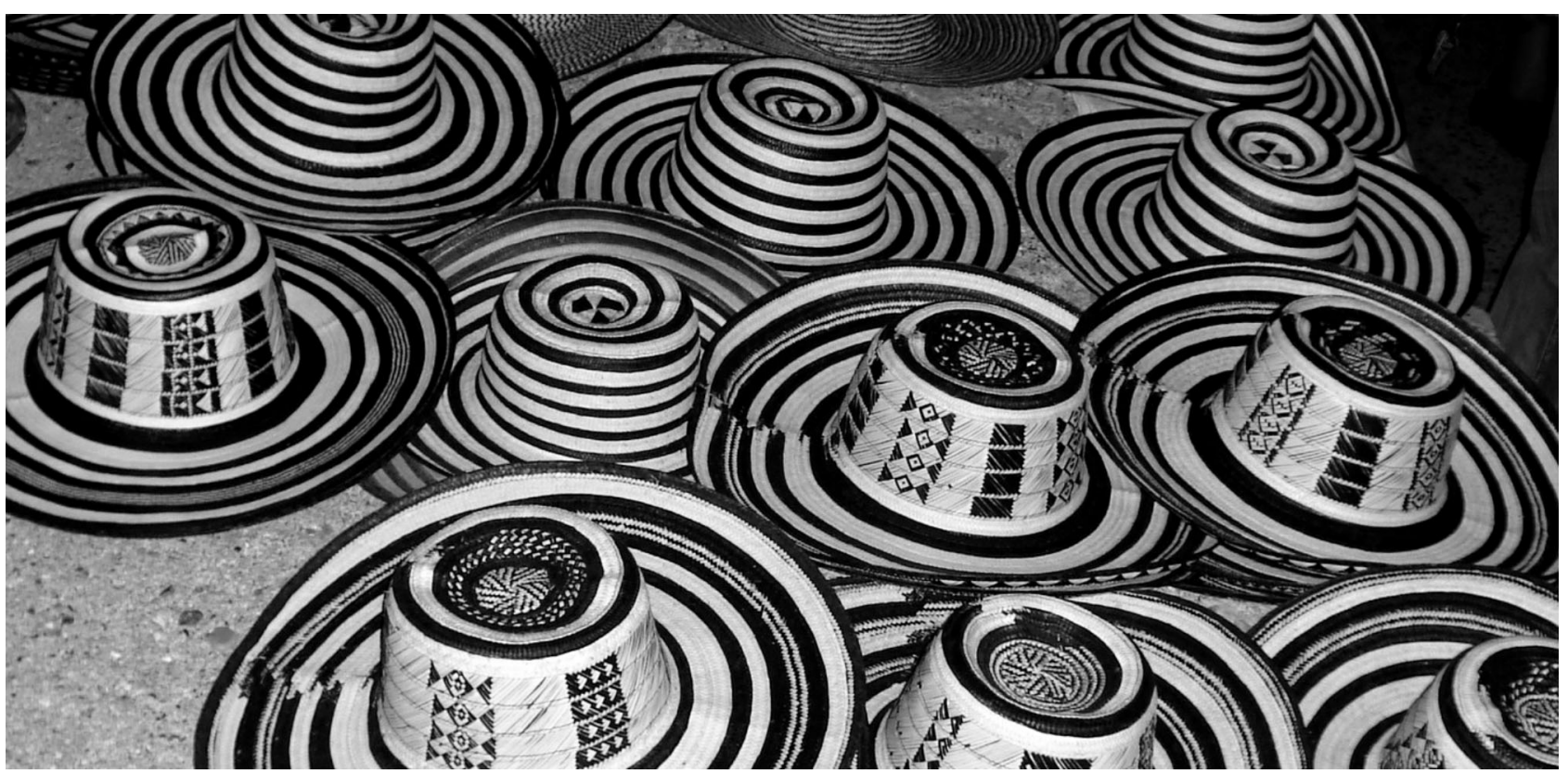


la llustración con la institución de la Expedición Botánica, la encargada de despertar el interés por el conocimiento de la riqueza del suelo nacional y de la naturaleza que se consideraba con orgullo, "única en el mundo". Ese orgullo se transformó en signo de identidad.

Hacia 1808 Francisco José de Caldas, prócer ilustrado originario de Popayán, planteó de modo dramático el problema de la originalidad: " $\mathrm{i}$ Qué dudas, qué suerte tan triste la de un americano! Después de muchos trabajos, si llega a encontrar alguna cosa nueva, lo más que puede decir es: 'No está en mis libros'" (Vergara y Vergara, 1974, 104).

Simón Bolivar se hizo consideraciones sobre la nacionalidad de modo negativo: "Mas nosotros, que apenas conservamos vestigios de lo que en otro tiempo fue, y que por otra parte no somos indios ni europeos (...)" (Bolívar, 1982, 166). Para subsanar esa angustia identitaria se recurrió durante esas épocas de lucha, a construir representaciones iconográficas. La pregunta podría ser ¿Cómo se construye la representación de la identidad?

Uno de los primeros signos que sirvieron a la representación fue la imagen de América transformada en el concepto de patria. Una obra en particular Post Nubila Faebus'. SIMÓN BOLIVAR, LIBERTADOR y Padre de la Patria demuestra "la forma en que la iconografía insurgente imaginaba la patria: una princesa indígena" (Earle, 2007).

Aunque el nombre actual y reciente del cuadro es "Bolívar y la alegoría de América", el pintor recibió la comisión de hacer una obra que honrara a Bolivar y la Libertad. Tal fue la intensión de los peticionarios según la reseña publicada un mes después por la Gazeta Extraordinaria de Bogotá del 17 de octubre del 1819 y reproducida tardíamente en el Correo del Orinoco, el sábado 20 de enero de 1820. El texto dice lo siguiente: "La Asamblea de Notables, encabezada por Tiburcio Echevarría, quiso agasajar a Bolívar y a sus tropas después del triunfo de Boyacá, para lo cual creó una condecoración: la Cruz de Boyacá y dispuso la realización de una pintura: Baxo el Dosel del Cabildo de la Ciudad, será colocado un quadro emblemático, en que se reconocerá la LIBERTAD sostenida por el brazo del General BOLíVAR ${ }^{2}$. No obstante el pintor que fue quien escribió la cartela, no colocó en ella la palabra "Libertad" sino la palabra "Patria".
El pintor Alberto Urdaneta dio en 1883 una versión minuciosa de la primera exhibición del cuadro: "Fue este retrato de BOLÍVAR el que en la función preparada y llevada a cabo en honor del LIBERTADOR en septiembre de 1819, se le presentó sobre un tablado, en la plaza de Bogotá, por la señorita Dolores Vargas, que más tarde fue esposa del

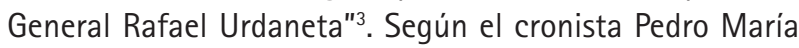
Ibáñez "La apoteosis acordada por la asamblea de notables en días anteriores se verificó el 18 de septiembre. Desde los albores de ese día apareció engalanada la casa consistorial con un cuadro al óleo, emblemático de la libertad, sostenida por el brazo de Bolívar, que aún se conserva en el Museo Nacional"4. A partir de alli se pueden establecer las transmutaciones que han sufrido en este cuadro los conceptos de Libertad $\rightarrow$ Patria $\rightarrow$ Colombia $\rightarrow$ Alegoria de América.

Pedro José Figueroa (1770-1838) fue el primer pintor que contrató el gobierno de Bogotá para hacer un retrato del Libertador cuando este se encontraba recién llegado de la batalla de Boyacá. La mayoría de los retratos de Bolivar venían de Europa y procedían de la iconografía napoleónica o de pintores casuales que lo retrataron en medio de la guerra antes de la batalla de Boyacá.

Se ignora el momento en que el pintor conoció a Bolívar. Pudo ser cuando éste se tomó a Bogotá en 1814 durante la guerra de federalistas y centralistas. Tampoco se sabe si lo vio entrar triunfante después de Boyacá. Vergara y Sandino afirman en una crónica sobre la exposición que hizo Urdaneta en 1886 que Figueroa visitó a Bolivar en Palacio para retratarlo, pero esta es una confusión de los escritores a partir de la equivocación de los nombres de los pintores Figueroa y Espinosa. Este último fue quien visitó a Bolívar en el palacio presidencial.

La historia más cercana a la verdad es la que narra que el pintor Pedro José Figueroa se encontraba pintando un retrato de Fernando VII a solicitud de un oidor en agosto de 1819, cuando se enteró del triunfo de Boyacá y lleno de temor, pintó encima a SIMÓN BOLIVAR, LIBERTADOR y Padre de la Patria (fig. 2). Aunque la historia total no ha podido documentarse, existen unas pruebas irrefutables como la radiografía en la que aparece otro retrato en el fondo, colocado de manera horizontal, de un personaje que no se sabe si es Fernando VII o Pablo Morillo. El historiador Gabriel Giraldo Jaramillo narra sin mencionar las fuentes 
que "en el año de 1819 y poco después del triunfo de los patriotas en Boyacá, dirige Figueroa una carta a las autoridades dándoles cuenta de un retrato de Fernando VII que le encargó el oidor don Pablo Chica y que se vio obligado a borrar el 9 de agosto, 'temeroso de alguna desgracia, por la espantosa anarquía en que nos vimos aquel dia'; se le solicita que entregue el retrato o los sesenta pesos que por el pagaron; pero el pintor humildemente pide que se le conceda un plazo, pues 'en cuanto al busto ya ha oído Vuestra excelencia lo ocurrido; el dinero me es imposible devolverlo porque mi notoria pobreza no me permite"" (Giraldo Jaramillo, 1980, 163).

Por el aspecto que el pintor le dio a Bolívar en el cuadro se observa que no le tenía mucho afecto. Lo que sorprende es que decida acompañarlo con la imagen clásica de América, tan de acuerdo con el ideal americanista del Libertador. No se sabe de qué grabado partió Figueroa para la figura alegórica acompañante pero ésta procede en último término

2. Pedro José Figueroa, Bolívar y la Alegoría de América, 1819. Óleo sobre lienzo. Casa Museo Quinta de Bolívar, Bogotá.

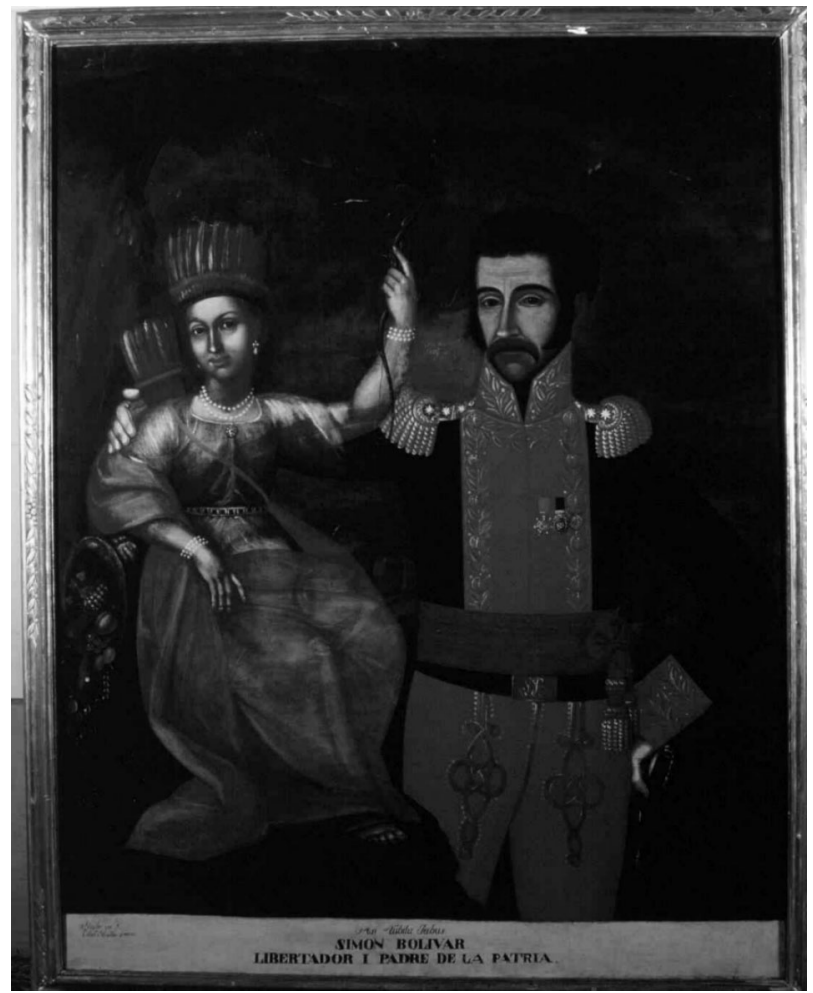

de la imagen de la Iconologia de Cesare Ripa (1555-1622) publicada en 1593.

Aunque la imagen de América de Ripa, es una mujer de pie y no se parece a la joven utilizada por Figueroa, los atributos son los mismos: el carcaj, el arco, la flecha, un cocodrilo y la corona de plumas. Se le añadió una cornucopia, con frutos supuestamente tropicales, que se había agregado en versiones europeas posteriores a Ripa. La pequeña imagen de "la patria" que acompaña al Libertador está sentada, vestida muy recatadamente y no posee rasgos indigenas. Detrás de la figura hay una palma y un paisaje.

De la representación de América se encuentran huellas en la colonia. Algunas de ellas son las acuarelas de las ceremonias que se realizaron en 1808 en la población de Honda, con motivo de la jura de Fernando VII (Gutiérrez y Gutiérrez Viñuales, 2006, 71).

El investigador Juan Ricardo Rey menciona una acuarela de los mismos festejos y del mismo año, pero con fecha diferente: 11 de septiembre de 1808: "Con la llegada del delegado español Juan José Samaniego se hizo la celebración. Según José Acevedo y Gómez, encargado del cabildo de Santafé, cuenta que se exhibió un emblema con 'dos matronas de bella actitud, sentadas en dos continentes divididos por el mar. La una representa a España, la otra América, con sus respectivos atributos cada una'" (Rey, 2007, 39-40).

Dentro del recorrido de la imagen de América que antecede a la obra de Figueroa se han encontrado dos grabados uno en metal y otro litográfico, uno inglés y otro francés que representan a Simón Bolivar/Jefe Supremo de la República/y Capitán General de la Armada de/Venezuela y Nueva Granada ${ }^{5}$. Los dos están orlados con la imagen de América que ostenta todos los atributos y en la mano derecha sostiene la lanza con el gorro frigio. Los dos están fechados en 1819. La fecha del grabado inglés es más explícita "primero de febrero de 1819", esto quiere decir que fue impreso siete meses antes de la obra de Figueroa. Se podría aventurar que la reunión de Bolívar y América en un cuadro ya era conocido antes de la batalla de Boyacá. ¿Cómo y cuándo llegaron estos grabados a Colombia es la pregunta? Tempranamente, por el interés político de los patriotas de aventurarse a la guerra de imágenes. 
Otra de las claves podría ser Francisco de Miranda, precursor de la iconografía de América convertida en patria: cuando llegó a Venezuela recibió el 5 de julio de 1811 la encomienda de diseñar los emblemas patrios, la bandera y el escudo (Quintero, 2006, 82). La bandera tenía los colores amarillo azul y rojo, ya usados por él en la fracasada campaña de 1806, a los que añadió en la parte superior la imagen de América con la lanza que soporta un gorro frigio. Juan Ricardo Rey propone la llegada del icono de América por la vía de Venezuela.

La obra de Figueroa fue ordenada para significar el concepto de patria. Si en un comienzo se aceptó con entusiasmo, durante el siglo XIX perdió reconocimiento. Ya no se evocaba en él a la patria. A comienzos del siglo XX la obra se encontraba casi abandonada en la Casa de Moneda. Cuando al director del Museo Nacional, el historiador Ernesto Restrepo Tirado le plantearon, en 1910, la necesidad de recoger todos los retratos de Bolívar que se encontraban en oficinas públicas para colocarlos en el Museo Nacional, esta pintura no era muy apreciada. Restrepo Tirado no manifiesta gran entusiasmo por esta pintura: "Retrato de Bolivar semejante en facciones al que lleva el número 103. A la derecha se ve una muchacha representante de la raza indígena, a la cual Bolívar echa el brazo por encima. Este retrato es obra del artista Espinosa (sic): 'Este retrato estaba en la Casa de Moneda, de donde se trajo al Museo por disposición del señor Ministro del Tesoro'" (Restrepo Tirado, 1917, 21).

Se necesitó de la transformación del gusto en la segunda mitad del siglo XX para que se reconocieran sus valores iconográficos. La historiadora del arte Marta Traba fue la gran admiradora y difusora de esta pintura:

"El retrato de Bolívar de 1819 es, sin duda, la pieza maestra de la iconografía bolivariana. El general de frente, con su gesto semi irónico, semi despectivo, apoya la mano derecha sobre el hombro de la pequeña república empenachada. La figurita femenina está sentada en una roca a manera de trono, pero su figura infantil y frágil desdice cualquier semejanza con la tradicional opulencia de las alegorías femeninas destinadas a expandirse en el espacio. En el costado izquierdo del cuadro, una palmera se inclina ligeramente sobre la república para enmarcarla. Debajo de la figura emerge la torpe y oscura cabeza de un cocodrilo y caen de un cuerno de la abundancia disimulado tras la república, algunas frutas tropicales. $L a$ figurita parece jugar mientras levanta el dedo índice hacia arriba, obedeciendo más al gesto leve, tierno y protector de la mano del Libertador, que a su propia voluntad de dominio. Simbólicamente, la pequeña república es la hija del Libertador, él la muestra con cierto orgullo burlón y le dirige sus gestos" (Traba, 1974, 48).

En el presente es un icono. Ha participado en exposiciones internacionales y ha sido solicitada para publicaciones. Sin embargo, sabemos que es Bolívar por el rótulo, no por tratarse de un retrato realista o reconocido. Se puede afirmar que el artista creó el icono a sus espaldas. Hay unos elementos que pueden dar la clave de su popularidad: 1. El planismo que está de acuerdo con la pintura Pop de la década de 1960: Si se comparan las dos figuras se observa que el cuerpo del Libertador es plano definido por el uniforme. El rojo y el azul no tienen sombra ni matices. La cinta de la cintura casi recta y los alamares del uniforme son también planos. El cuerpo de la patria tiene volumen definido a través del traje y del velo rosado que lo cubre. 2. El primitivismo: Es una imagen sencilla realizada tal vez con disgusto del pintor hacia el personaje o por su propia incapacidad para tratar un tema tan complicado; por ello hizo abstracción de detalles realistas. Acá también se puede hablar que por accidente o gracias a la crítica de arte se convirtió en una "imagen esencial".

\section{El Árbol de la Libertad}

El concepto de Árbol de Libertad llegó tempranamente, en el decenio de 1790, al Nuevo Reino de Granada. En un comienzo, durante el virreinato, causaba disgusto porque se relacionaba con la revolución francesa y la libertad. En el Papel Periódico de Santafé de Bogotá se advierte la antipatía hacia esta alegoría del director cubano Manuel del Socorro Rodríguez quien se refiere al "árbol de la libertad" con desprecio:
Si en la actual constitución
Todo es tiranía y maldad
Árbol de la libertad
¿Quales, di, tus frutos son?
¡Oh Numen de la razón,
En vano no es con tanto anhelo
Pedirle alivio y consuelo! 
Ea pues, si ni Árbol, ni Diosa,

Protegeís ninguna cosa

Descended los dos al suelo6.

El concepto sobre este símbolo cambió debido a la declaración de independencia. El desprecio se convirtió en aprecio. Se creó un ceremonial y la noción de libertad fue reemplazada por la de patria. Después de 1810, durante el gobierno de Nariño, el árbol de la libertad se rodeó de un rito pleno de emblemas: Se plantaba un árbol en las plazas de las distintas poblaciones; unas veces era un arrayán, otras un cerezo. Se vestía de indígena a una de las señoritas del lugar para representar a la patria. Antonio Nariño ordenó plantar un arrayán de cinco varas de alto como "Árbol de la Libertad" en la plaza de Bogotá, el 29 de abril de 1813. Los ejemplos literarios abundan; el más descriptivo es la narración de un evento el 4 de febrero de1816 en el Diario de la independencia de José María Caballero que dice: "Domingo 4. Se fue mucha gente a Bogotá (nombre antiguo de Funza) y plantaron en dicha parroquia el árbol de la libertad; llevaron un cerezo con tierra y una gorra colorada a la mitad de la plaza, donde había un hoyo dispuesto. Iba una india con su corona bien dispuesta, con su corona de plumas. Salió una gran comitiva, con una música de la casa del cura, D. Policarpo Jiménez, y muchos sacerdotes y caballeros y señoras. Dieron la vuelta a la plaza y en llegando al lugar del hoyo dijo la india: 'Planto aquí el árbol que nuestras enemigos arrancaron con crueldad de este mismo lugar' (Caballero, 1974, 200). Era usual que los realistas para burlarse de los patriotas arrancaran el árbol de la libertad y sembraban en su lugar un arboloco. 'Como por irrisión', dice Espinosa" (Espinosa, 1876, 94).

El concepto de patria estaba muy arraigado. Cuando José María Espinosa narra su huida, después de la derrota de las tropas de Nariño, se hace evidente el culto por la Patria: En Timaná

"se armó en efecto un baile en una de las casa de la plaza, con un mal violín, guitarra, pandereta y bombo, o tambora. Bailamos al estilo del país y bebimos en abundancia un mal licor que fabricaban allí y que llamaban vinete, con el cual nos alegramos más de lo necesario. Mi amigo comenzó a gritar entusiasmado ¡Viva la Pacha! (...) Yo le pregunté qué significaba esto y el me dijo al oído y llevándome aparte, que quería decir 'viva la Patria' (...) que para disimular decían
¡Viva la Pacha o la Pachita! 'Dejémonos de eso' le contesté, y grité con toda la fuerza de mis pulmones, y en la mitad de la sala: iiViva la Patria!... Este grito resonó como un trueno formidable en la reunión; el baile cesó instantáneamente (...) y como por encanto nos quedamos sólo los gritones y el de la guitarra que estaba dormido sobre un escaño" (Espinosa, 1876, 223).

Esta hazaña le costó una nueva prisión a Espinosa.

Con el paso del tiempo el patriotismo fue cuestionado. Según el historiador Eduardo Posada Carbó

"La prolongada crisis del país ha desatado reclamos de 'patria' que suelen ser despreciados por los intelectuales. No les falta algo de razón. La expresión 'patria' tiende a identificase con los instintos primarios y xenófobos propiciados por el fascismo. Se la socia con el belicismo, el culto al estado, la demagogia y las ambiciones de los tiranos. Importa reconocer que hoy existen esfuerzos académicos por reexaminar la validez del patriotismo, por rescatarlo de sus connotaciones repugnantes. No obstante existen esfuerzos para rescatar el origen republicano del término -como las sugeridas por Mauricio Virola-, el patriotismo no se define en las lealtades con la unidad étnica o cultural, sino en el apego a los valores de la libertad y a las instituciones que le dan sustento" (Posada Carbó, 2006, 300).

Así como se encuentran acuarelas de la jura de Fernando VII en Honda, no se han ubicado imágenes de la ceremonia del árbol de la libertad. De la patria si existen imágenes: en 1812 se encuentra una iconografía que simboliza a Cartagena de Indias: una moneda del Estado de Cartagena y un sello de la Constitución del Estado de Cartagena. Esto demuestra que no sólo era reconocida como el continente americano sino utilizada con fines patrióticos: estos dos ejemplos se relacionan con la independencia de Cartagena, por lo tanto la india ya no representa América sino es el emblema de una ciudad. Las dos imágenes son muy semejantes y la mujer aparece recostada contra el árbol de la libertad que es una palmera. Las dos tienen los atributos del icono clásico: la corona de plumas, el arco y el carcaj. Sin embargo le añaden nuevos elementos simbólicos: las cadenas rotas, el ave que come la granada entreabierta -Nueva Granada- que sostiene la india en la mano derecha. El paisaje presenta modificaciones. En la moneda muestra un Ilano y dos palmeras; en el sello dos 
suaves colinas cada una con construcciones semejantes a iglesias. Se afirma que una de estas colinas es el cerro de la Popa.

Una obra de autor anónimo, en la casa Museo 20 de Julio de 1810, representa a la India de la Libertad (fig. 3) recostada en el tronco de un árbol y sostiene en una mano una lanza con el gorro frigio. Su encanto radica en el primitivismo y en el físico de la modelo. Al contrario de la figura que acompaña a Bolivar en la obra de Figueroa, esta tiene tipo indígena y se encuentra semidesnuda. También aparece el nuevo atributo que es el gorro frigio engastado en una lanza.

Esta imagen debió tener valor simbólico en la independencia; debió reconocerse como representación de la patria. Después perdió estas connotaciones que fue recuperando por razones estéticas y étnicas en la segunda mitad del siglo XX.

3. Anónimo, India de la Libertad, c. 1819. Óleo sobre lienzo. Museo 20 de Julio, Bogotá.

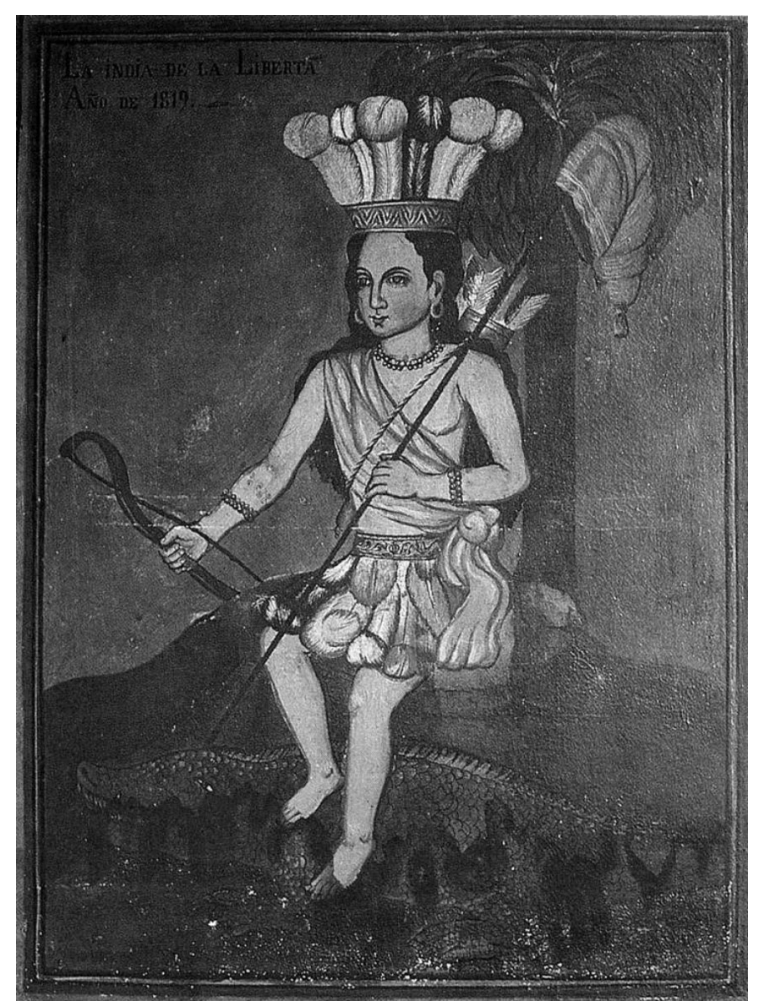

\section{EL ORO Y EL POPORO}

De cómo llegó a convertirse en icono el Poporo quimbaya, propiedad del Museo del Oro del Banco de la República, con el registro n. ${ }^{\circ} 15$, es otra historia. Su imagen fue difundida desde el siglo XIX en la modalidad fotográfica de tarjetas de visita dentro de una colección que comprendía especies botánicas como las orquídeas y la palma de cera. Se puede afirmar que quienes realizaron esta curiosa colección, los fotógrafos Wills y Restrepo, al incluir una pieza prehispánica como el Poporo quimbaya, conocida en el siglo XIX como "jarra de oro", no estaban haciendo una colección de ciencias naturales sino que estaban difundiendo imágenes que consideraban emblemáticas de la nacionalidad. Por la misma época se difundió una colección también de tarjetas de visita de tipos regionales. Esta colección de cerca de cien fotografías, hoy perdida, perteneció al Museo Nacional a finales del siglo XIX.

Una de las causas por las cuales el Poporo se convirtió en icono, entre las cerca de 33.600 piezas que posee el Museo del Oro, puede ser la temprana difusión en esta colección fotográfica. Sin embargo, de todas las imágenes de ese álbum de tarjetas de visita la que más ha trascendido es el Poporo quimbaya. En cambio, la calidad de otras dos imágenes fotográficas como la catleya Triana y la palma de cera que son emblemas de la nación, no están muy definidas, no se fijan en la mente del observador, no se captan rápidamente. El Poporo conlleva por su forma lo que en el estudio de los iconos se denomina "imagen esencial". Se puede pensar que otra causa de su éxito iconográfico es su forma que permite una lectura desde la abstracción. Posee una geometría casi perfecta: una base ligera, circular, de figuras sencillas caladas, que soporta una esfera cuyo desarrollo se interrumpe por medio de una orla con un diseño simple, de donde sale un cilindro que primero se adelgaza para luego ampliarse para dar paso a cuatro segmentos circulares que a su vez soportan cuatro esferas perfectas (fig. 4). El ojo aprehende rápidamente la forma y causa un doble placer: primero el goce mental que produce la forma geométrica y el sensorial ante lo rotundo. Otro placer proviene del material, el oro, que culturalmente remite al histórico mito de "El Dorado". Lo de menos es su uso -porque se trata de objeto utilitario- satanizado por el narcotráfico.

Otra causa de su iconización puede ser el trabajo museológico alrededor de esta pieza: el Banco de la República 
4. Poporo, Elaborado en oro fino. Quimbaya. Museo del Oro, Bogotá.

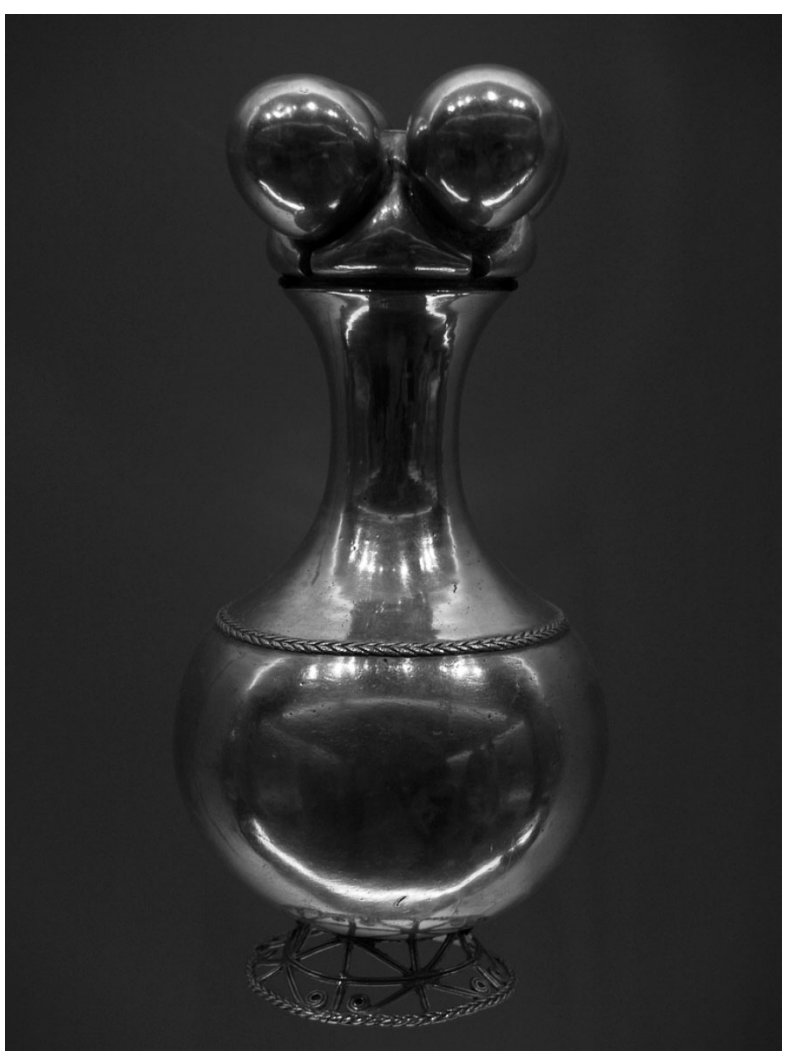

la adquirió para su colección al crear el Museo del Oro en 1939 y lo entronizó cuando construyó un edificio especial, en 1960. Para comprender mejor su papel en el terreno iconográfico se le puede contraponer La balsa de oro, que ingresó al Museo casi treinta años después. Su material es el mismo del Poporo, pero su diseño confuso no se capta claramente por el intelecto sino a causa de sus referencias a las costumbres del pasado indígena. Su forma obedece más a una narración histórica.

Los dos han sido iconizados, pero el proceso va más allá: se han convertido en representaciones de la nacionalidad. Existen más poporos, y más balsas en el Museo del Oro y en museos de Europa, pero más allá de la admiración por la destreza técnica de los antepasados, el fenómeno trasciende el campo artístico "para integrarse en la memoria colectiva".

\section{La Chinca, Representación de la nacionalidad}

De como se logró una obra arquetípica en la sociedad colonial, se deduce de la Virgen de Chiquinquirá (La Chinca), una imagen "creada" en 1556 por el pintor de Tunja, Alfonso de Narváez (Siglo XVI-1583). Se trata de una combinación de tres imágenes dadas, que nunca habían estado reunidas, procedentes seguramente de grabados; una especie de collage: en el centro, la Virgen del Rosario, a los lados de manera independiente se encuentran colocados San Antonio y San Andrés (fig. 5). Según José Manuel Groot La explicación de este conjunto es que el pintor, quien utilizó por soporte una manta indígena, de algodón, al pintar la Virgen en el centro le sobraron dos espacios, en uno de ellos colocó la imagen reconocida de San Antonio y en el otro a San Andrés en honor al donante, el encomendero Antonio de Santana, y al intermediario, el lego fray Andrés Jadraque. Como se puede apreciar, la relación entre las figuras no obedece a ninguna idea, ni a la narración de un hecho religioso. Según Fray Pedro de Tovar y Buenaventura, Maria Ramos, una parienta política del encomendero Antonio de Santana, ya fallecido, llegó de Tunja a Chiquinquirá a una casa de su familia. Encontró el cuadro abandonado y roto. Se dice que servía para secar el maíz o el trigo. Allí inició una serie de oraciones a la Virgen. El 26 de diciembre de 1586, pasó por allí una indígena llamada Isabel, con un niño de la mano. El niño vio un resplandor y llamó la atención de su madre quien asombrada gritó: "Mire, mire señora, que la madre de Dios está en vuestro asiento y parece que se está quemando". Era el milagro de la renovación.

La unión de tres imágenes no originales produjeron un icono original, famoso en América Latina. El cuadro se restauró en presencia de un niño y una mujer humilde. Este conjunto pudo ser vetado por el Concilio de Trento porque el pintor representó un tema religioso y no se hizo aconsejar de teólogos. ¿Pero cuales teólogos podrían haberlo aconsejado sobre iconografía en Tunja a finales del siglo XVI?

¿Cuántas imágenes de la Virgen de Chiquinquirá se encuentran en América? Cientos de ellas. Se difundió por medio de grabados y exvotos en todas las ciudades de Colombia, en Venezuela, Ecuador y Centroamérica. Esa imagen cumple lo que se llama el carácter didáctico del 
5. Bernardo Bitti, Virgen de Chiquinquirá, Primera mitad s. XVII. Óleo sobre lienzo. Colección Humberto Luján.

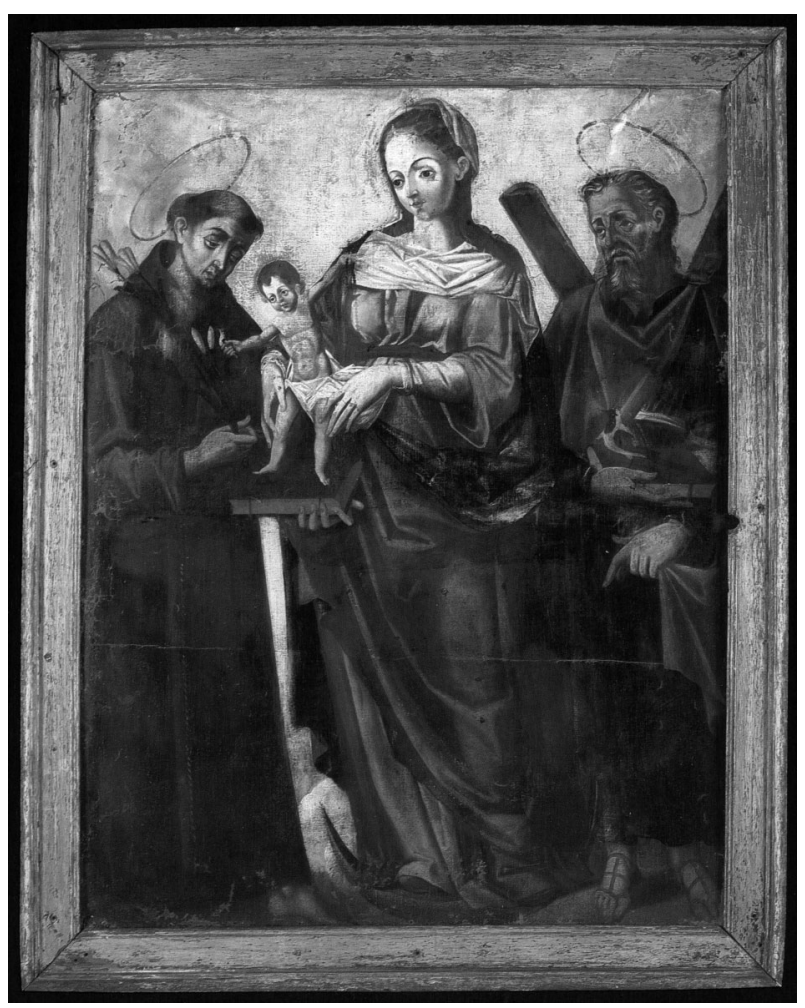

arte en la colonia porque se difunde la imagen de la Virgen del Rosario, un tema promovido por los dominicos.

La imagen no sólo sirvió con fines estrictamente piadosos sino se convirtió también en emblema nacional, desde la independencia. Dada la riqueza con que fue engalanada durante la colonia -entre ellos el fajón de brillantes y esmeraldas que remitió la duquesa de Alba-, sus tesoros eran famosos. Los patriotas solicitaron en préstamo algunas de sus alhajas para pagar el costo de la guerra. Otro patriota, el francés Manuel Serviez, comandante en jefe de las Provincias Unidas tomó el cuadro del templo y lo llevó como estandarte. El domingo 5 de mayo de 1816, entró a Bogotá "con toda la infantería, a las diez del día, y en medio de los dos primeros batallones traían la milagrosa imagen de Nuestra Señora de Chiquinquirá, la original, encajonada y envuelta en un toldo (...) siguió camino derecho por el puente de Santa Calina, para Cáqueza (...). El llevarse Serviez la Virgen no sé a qué se pueda atribuir. Yo me parece que el fin que él se propuso fue que como conoció que era una imagen a que todos tienen en tanta veneración, diría: pues llevándola, todo el mundo la sigue y los soldados pelearán con más valor y confianza, no porque él le tuviese alguna fe a Nuestra Señora, pues según dicen no era cristiano" (Caballero, 1974, 216). Fue excomulgado por este acto patriótico y para su desgracia fue derrotado. El presidente Fernández Madrid encomendó a la Virgen la lucha contra la reconquista española en cabeza de Pablo Morillo y prometió que los primeros trofeos de guerra que llegasen los colocaría a los pies de la milagrosa imagen (Álvarez White, 1986, 18-19).

Hasta el presente, la Virgen de Chiquinquirá continúa siendo una devoción continental y al mismo tiempo una representación de la nacionalidad.

\section{Crear iconos de la nacionalidad}

¿Quién crea las representaciones de la nacionalidad? ¿El artista, el pueblo, el museo? Es importante conocer cuáles han sido los mecanismos para que ciertas imágenes se hayan convertido en representativas y cuáles tienen posibilidades de acceder a ser características de valores nacionales. Es necesario situarse en la época del pintor, en la literatura y el pensamiento de su tiempo para develar cómo se crea un icono. Ya Gombrich había hablado del "poder de las imágenes" al referirse en cierta forma a la unión de magia e imagen en la prehistoria (Gombrich, 1981, 39). En el presente se pueden crear imágenes poderosas, con otra magia que son los medios de comunicación. Por ello se "nos debe prevenir constantemente contra las falacias de imágenes fáciles y falsas que nos acechan en nuestro bagaje cultural" (Briesemesiter, 1992, X). Por ejemplo, la Barbie, es una falacia, un producto del mercadeo. Los museos gracias a ese bagaje cultural que preservan, tienen un seguro, en cierta forma, contra las imágenes "fáciles y falsas".

Para aproximarse al tema de cómo una pieza se convierte en representación de la nacionalidad es necesario acudir a las ciencias iconográficas e iconológicas.

"En nuestra época de comunicación televisiva y de publicidad omnipresente nos damos cuenta con más sensibilidad del 
poderoso impacto que ejercen sobre nosotros las imágenes [...] Las imágenes traducen lo nunca visto ni oído, lo nuevo en formas comprensibles y accesibles a la visión. Las imágenes no proporcionan un reflejo exacto, directo o una reproducción fotográficamente fiel de algo o de alguien, sino que pasan por el filtro de la abstracción. Siempre dejan algo fuera, siempre silencian algún detalle, sólo trasmiten un mensaje parcial pretendiendo, sin embargo, cifrar la totalidad. A pesar de ello, las imágenes no alcanzan la percepción objetiva, no son puras concepciones lógicas, sino aproximaciones subjetivas, aspectos en el sentido originario de la palabra, modos de ver que surgen en un contexto socio-histórico y cultural muy complejo.

"Según nuestra condición humana sólo somos capaces de captar realidades por medio de imágenes. (...) Como el estudio iconológico lo revela claramente, despliegan un dinamismo extraordinario que se incrusta en expresiones literarias o artísticas para formar una cadena fuerte de transmisión. Por otra parte, las imágenes poseen una enorme fuerza de persistencia. (...) Pueden convertirse en pautas estereotipadas con una vida y funcionalidad propias que corroboran los cánones estéticos, los valores morales, mitos, leyendas, etc. Las imágenes se integran en la memoria colectiva" (Briesemeister, 1992, IX).

Malevich, pintor de la vanguardia rusa, creó lo que él denominaba "el icono de nuestro tiempo". Conocedor de los iconos de iglesia ortodoxa, al instalar su exposición Suprematismo de la pintura, en Petrogrado, en 1915, colocó una pequeña obra en un rincón, como alusión a la situación de estas imágenes en las casas rusas, que llamó Cuadrángulo hoy conocido como Cuadrado negro sobre fondo blanco.

"Para Malevich, el icono suprematista debía crear una nueva relación pictórica, más allá del icono ortodoxo y del cuadro de caballete, haciendo aparecer un nuevo sitio; se trata de la expresión imagen esencial, despojada del fárrago figurativo, oponiéndose al imago, a la efigie, llevada a lo único. Malevich no estuvo influenciado únicamente por el lado formal del icono; logró aprehender por una intuición genial la cuestión filosófico-teológica del icono; es decir, que la presencia real no se encuentra en la imagen simbólica representada, sino en la relación de esta última con el modelo ausente: la invisibilidad de la imagen es la fuente de la visibilidad del icono" (Mercadé, 2003, 48-49).

Cuando se reflexiona sobre la representación de la nación a partir de la Independencia se deduce, en primer lugar, que no existe una colección de imágenes tan abundante y variada como la del período de la Independencia. Etapas importantes de la historia de Colombia hasta mediados del siglo XX no están representadas por iconos. No se trata de crear emblemas para propaganda política, sino buscar que la imagen pueda calar en el imaginario popular para acrecentar su reconocimiento como nación. Si se examinan los libros de historia contemporánea del siglo $X X$, se encuentra que son pocos los libros con imágenes poderosas. La ausencia de iconografía ha producido un vacío en el imaginario popular. Se puede preguntar si esto ha sido deliberado, causado en cierta forma por la derrota de las ideologías, o por la conservación del país que siguió a esta derrota, o si se trata de un hecho casual porque no hubo un arte de prestancia como la pintura y la escultura, que respondiera con imágenes a la nueva historia. No hubo un Malevich que creara el "icono de nuestro tiempo".

Así como la revista Semana se animó a buscar símbolos del país, el Museo Nacional de Colombia estuvo preocupado en los últimos tiempos por la creación de iconos. En ello trabajó hace un par de años con unas estrategias encaminadas hacia la representabilidad de la nación.

En primer lugar se indagó sobre la manera como la representación nacional debe corresponder a una idea. En este caso se trató de incrementar valores de identidad, de nación. En el Proyecto Identidad Colombia se seleccionaron piezas dentro del Museo que por sus condiciones pudieran formar parte del imaginario popular. Años después se realizó un proyecto para la exposición Colombia, cuerpo y espíritu, que nunca se llevó a cabo.

En el primer proyecto las obras debían someterse a un examen en cuanto a su valor histórico, estético, trayectoria y su iconicidad. Esto es, sus atributos, su nombre. El primer problema, al aproximarse al tema, era la identificación del sujeto: ¿Qué o quién es y cuáles sus principales atributos?

Se acudió a una estrategia inédita que se denominó "anteimagen" que consistía en que cuando el espectador o el público accedieran al museo ya traían en mente una imagen particular. Esta actitud se debía derivar de la reiteración de la imagen por distintos medios y la publicación de estudios serios de su valor. De este modo, el objeto de 
su visita tuviera por finalidad no recorrer el museo para ver objetos, sino en reconocer de antemano la pieza que buscaba con furor.

\section{Conclusión}

El término icono, en sí mismo, ha sido adoptado por las artes plásticas, la publicidad comercial y los computadores. A partir de estos últimos, para nadie es un misterio la palabra icono. Dentro de la selección de sabios de la revista Semana se pensó en toda clase de iconos de la nacionalidad. No se mencionó Cien años de soledad ni a su autor, pero se eligió un lugar imaginario llamado Macondo. Se ignoraron las novelas Manuela, de Eugenio Díaz, María, de Jorge Isaac y Frutos de mi tierra de Tomás Carrasquilla. Se derrotó a la fotografía. Se dividieron los candidatos a símbolos en secciones como sitios arqueológicos, medio ambiente, mitología, arquitectura, artesanías, tradiciones orales, clásicos símbolos patrios y la geografía, etc. "La lista podría ser eterna. Por que en el imaginario febril de los colombianos de todas las épocas y pelambres siempre ha habido y habrá infinidad de motivos de orgullo que se reflejan en clisés que de tanto repetirse se vuelven verdades colectivas jamás comprobadas y que muchas veces los mismos hechos se encargan de desmentir de manera cruel y despiadada" (Arias, 2006, 150).

Las distintas épocas tuvieron sus representaciones nacionales; algunas sobrevivieron otras murieron. Con motivo de las celebraciones de los 200 años de la Independencia en Iberoamérica, la discusión se ha acentuado. Posada Carbó durante el 2006 escribió agudas reflexiones sobre el término "representación" que considera como el tema central de ese especial aniversario. "¿La representación? Si, claro, ¿no fueron acaso las protestas frente a la falta adecuada de representación americana en la metrópoli las que desataron los procesos independentistas? (...) El porvenir de la democracia en Latinoamérica exige una revaloración de su componente fundamental: la representación" (Posada Carbó, 2006, 5). Si bien la lucha por estas representaciones de carácter político tiene actualidad, de la misma manera las iconografías nacionales merecen atención. Su autenticidad e identificación se refleja en la pregunta persistente sobre la identidad en Colombia.

\section{NOTAS}

1 Después de las tinieblas sale el sol.

2 Correo del Orinoco 1818-1821. Reproducción facsimilar, Bucaramanga, Gerardo Rivas Moreno, 1998, p. 197.

3 Papel periódico ilustrado, año II, N.os 46 a 48, Bogotá, 24 de julio de 1883 , p. 422.

4 Pedro María Ibáñez, Crónicas de Bogotá, tomo IV, Bogotá, Imprenta Nacional, 1914, pp. 58-59. En la actualidad no se encuentra en el Museo Nacional. Fue trasladado a la Quinta de Bolivar por el Ministerio de obras en el decenio de 1970, cuando se le hizo una restauración de este inmueble.

Recibido: 4 de marzo de 2008

Aceptado: 10 de mayo de 2008
5 Simón Bolivar/Supreme Chief of the Republic/and Captain general of the
Armies of/Venezuela and New Granada.

6 Papel Periódico de Santafé de Bogotá, 11 julio, 1794, tomo IV, p. 780, n. 150 .

\section{BIBLIOGRAFÍA}

Álvarez White, María Cecilia (1986): Chiquinquirá Arte y Milagro, Bogotá, Litografía Arco.

Arias, Eduardo (2006): "País de mitómanos", Revista Semana, Bogotá, Edición Especial, n. ${ }^{\circ} 1.260,26$ de junio.

Bolivar, Simón (1982): Obras cartas, proclamas y discursos, vol. 1, Caracas, Ediciones de la CANTV.

Briesemeister, Dietrich (1992): "Prólogo", en Santiago Sebastián, Iconografía del 
indio americano siglos XVI-XVII, Madrid, Ediciones Tuero.

Caballero, José María (1974): Diario de la independencia, Bogotá, Biblioteca Banco Popular, volumen 71.

Earle, Rebecca (2007): "La iconografía de la independencia en la Nueva Granada", VII Ponencia para el Simposio sobre la Historia de Cartagena: La ciudad en la época de la Independencia, 18081821, 12 a 14 de septiembre.

Espinosa, José María (1876): Memorias de un Abanderado, Bogotá, Imprenta El Tradicionista.

Freund, Giséle (1993): La fotografía como documento social, México, Gustavo Gili.

Giraldo Jaramillo, Gabriel (1980): La miniatura, la pintura y el grabado en Colombia, Bogotá, Colcultura.

Gombrich, Ernst H. (1981): Historia del Arte, Madrid, Alianza Forma.

Gombrich, Ernst (1986): Imágenes simbólicas, Madrid, Alianza Forma.

Gutiérrez Ramón y Gutiérrez Viñuales, Rodrigo (2006): América y España imágenes para una historia Independencia e identidad 1805-1925, Madrid, Fundación MAPFRE, Instituto de Cultura.

Hall, James (1979): Dictionary of Subjects \& Symbols in Art, Revised Edition USA, IconEditions.

Hall, James (1995): Ilustrated Dictionary of Symbols in Easter and Western Art, USA, IconEditions.

Hernández de Alba, Gonzalo (1989): Los árboles de la Libertad, Bogotá, Planeta.

Ibáñez, Pedro María (1914): Crónicas de Bogotá, tomo IV, Bogotá, Imprenta Nacional.

León, Aurora (1986): El museo: teoría, praxis y utopía, Madrid, Ed. Cátedra.

Marcadé, Jean-Claude (2003): Iconos rusos: desde la mística a la vanguardia, Bogotá, Banco de la República, Biblioteca Luis Ángel Arango.

Panofsky, Erwin (2001): Estudios sobre iconología, Madrid, Alianza Universidad.

Posada Carbó, Eduardo (2006): La Nación Soñada. Violencia, liberalismo y demo- cracia en Colombia, Bogotá, Editorial Norma.

Posada Carbó, Eduardo (2006): "El bicentenario y la representación", El Tiempo, 28 de abril.

Quintero, Inés (2006): Francisco de Miranda, Caracas, Biblioteca Gráfica Venezolana.

Restrepo Tirado, Ernesto (1917): Catálogo general del Museo de Bogotá, Bogotá, Imprenta Nacional.

Rey, Juan Ricardo (2007): "Colección de Numismática Los indígenas europeos: la 'India de la libertad'", Cuadernos de curaduría, Museo Nacional.

Sebastián, Santiago (1992): Iconografía del indio americano siglos XVI-XVII, Madrid, Ediciones Tuero.

Traba, Marta (1974): Historia abierta del arte colombiano, Cali, Ediciones $\mathrm{Mu}$ seo la Tertulia.

Vergara y Vergara, José María (1974): Historia de la literatura colombiana, tomo II, Bogotá, Biblioteca Banco Popular n. 64. 